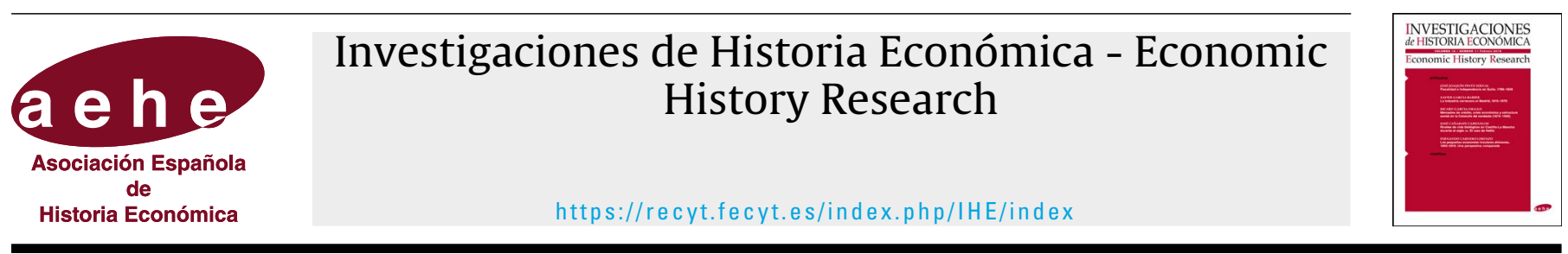

Ramón Carande Award

\title{
Convergence of public and private agendas in the shaping of the early modern Hispanic Monarchy: an economic-based approach
}

\section{Alberto Sánchez Camacho* $\mathbb{D}$ \\ European University Institute (Florence, Italy)}

\section{ARTICLE INFO}

\section{Article history:}

Recibido el 30 de abril de 2020

Aceptado el 6 agosto de 2020

On-line el 16 de septiembre de 2020

\section{JEL classification:}

N23

043

\section{Keywords:}

Non-state actors

State-building process

Institutions

Hispanic Monarchy

\section{Códigos JEL:}

N23

043

\section{Palabras clave:}

Actores no estatales

Proceso de construcción del estado Instituciones

Monarquía hispánica

\begin{abstract}
A B S T R A C T
This article reviews the state-building process in the Hispanic Monarchy during the mid-sixteenth century through the analysis of the relationship between Genoese high-rank financiers and Castilian private entrepreneurs in the international market of wool. The article argues that these two social groups were state builders as they played a key role in the state formation after the first debt consolidation of Philip II in 1557. The outcomes of the research demonstrate that non-state actors organised as informal institutions could perform better in the state-building process than formal institutions in large polities. This work thus complements the recent literature about the decentralisation of effective power in early modern states.
\end{abstract}

@ 2020 Asociación Española de Historia Económica

\section{Convergencia de agendas públicas y privadas en la formación de la monarquía hispánica durante la edad moderna temprana: una aproximación económica}

\section{R E S U M E N}

Este artículo revisa el proceso de la construcción del estado en la monarquía hispánica a mediados del siglo xvl a través del análisis de las relaciones en grandes financieros genoveses y emprendedores privados castellanos en el mercado internacional de lana. El artículo defiende que estos dos grupos sociales participaron en la construcción del Estado porque jugaron un papel decisivo en su formación tras la primera consolidación de deuda de Felipe II en 1557. Los resultados de esta investigación demuestran que actores no estatales organizados como instituciones informales podían participar mejor en el proceso de construcción estatal que instituciones formales en grandes sistemas gubernativos. Este trabajo complementa así a la literatura reciente sobre la descentralización de poder efectivo en estados de la era moderna temprana.

(C) 2020 Asociación Española de Historia Económica

\footnotetext{
*Corresponding author: alberto.sanchez@eui.eu
} 


\section{Introduction}

This article argues that the interaction between independent entrepreneurs and their social networks with state institutions made the former participants of the state-building process. In this text, non-state civil actors are considered state-builders because their agency in the process involves more than bilateral contracts between the entrepreneur and the central state apparatus. The analysis of the strategies that the Genoese lending community employed between 1557 and 1559, when Philip II consolidated his short-term debt for the first time and theoretically weakened his credibility before financiers, demonstrates that private entrepreneurs collaborated with one another because they depended on royal institutions.

This article looks at the correspondence of high-rank royal officers together with financial reports and export duties to reveal the convergence of private agendas in the aid of the monarchy. Therefore, public service and private initiative intertwine in this text to propose a history of the early modern state construction that brings together "top-down" and "from below" perspectives.

This second section of the article introduces the historiography behind the state-building process of the Hispanic Monarchy to show the multiple existing approaches. The third part of the paper examines the causes and immediate consequences of the debt reschedule of Philip II of Spain in 1557. The fourth part brings together the connection between Genoese financiers and Castilian wool exporters to analyse their mutual role in the state construction. Finally, some brief conclusions close this article to recapitulate about the importance of nonstate actors in the construction of the early modern state.

\section{State-formation in the early modern period: The case of the Hispanic Monarchy}

Scholars have always struggled in their challenging task of defining the multidisciplinary concept of state. In general terms, state is understood as the result of human efforts to organise themselves in community. However, the characteristics of that state make it difficult to define with precision. Political sociologists, for example, use to base their studies on the Weberian view of state, which defines it as the form of human community (Gemeinschaft) which lays claim to the monopoly of the legitimated use of physical force in a limited geographical area (Waters and Waters, 2015, p. 136). In other words, the rule of law and violence characterizes what a state should be. The two elements require the development of institutions, either informal or formal ones, to be managed and enforce the control of the Weberian limited territory. Whereas informal institutions are based on norms of conduct, historical traditions or religious concepts usually enforced by private groups such as family, business, and the church, formal institutions are ruled by legal texts like constitutions and laws and enforced by judicial and administrative officials of the state (Keefer and Shirley, 2000, p. 96; Greif, 2006, p. 37). In this sense, states are born in territorial contestation with other communities also organised in institutions.

The formation of the early modern Hispanic Monarchy as a state has been object of study among scholars from multiple perspectives. The Weberian territorial limitation plays a central role in the definition of the Hispanic Monarchy. Traditional literature on this heterogeneous polity defined this state as a "composite monarchy" in comparison with other European, more centralistic, models (Elliott, 1992; Koenigsberger, 1978). Each realm was organised through their own institutions, thus legitimizing the management of resources, the distribution of justice, and the use of coercion. Beyond the legal and institutional separation of large polities, the Hispanic Monarchy consisted of jurisdictional fragmented territories in each realm that were interconnected with one another through the figure of the sovereign. Jurisdictional fragmentation is here considered as the contestation of sovereignty by local and regional powers, such as cities, corporations, or feudal lords (Epstein, 2002, p. 14).

However, the close link between the institutional separation of the Hispanic realms and the jurisdictional fragmentation in each of them has been considered an element that prevented its economic growth (ibid., p. 169). The main explanation for this outcome is linked to the lack of centralism and absolutist practices from central authorities. Jurisdictional fragmentation in the early modern Hispanic Monarchy thus contradicts the argument of North and Weingast regarding the cause of its "retarded long-run economic growth", which they based on absolutist practices (North and Weingast, 1989, p. 808). From the fiscal point of view, the existence of representative institutions, which defended the interests of urban elites rather than those of commoners, was way of preventing predatory practices from the sovereign. The Hispanic parliamentarism was the result of a process of political aggregation rather than integration that symbolised the existing polycentric division of effective power (Mazín Gómez, 2012, p. 27). No central parliament represented the interests of other territorial elites, though their decisions might have an effect in the rest of the monarchy.

The parliaments of the Hispanic Monarchy did not have the same importance in the political conglomerate of the monarchy. Although the monarchy embraced large parts of Europe and America by the 1550s, the Cortes of Castile were the most important representative institution of the ensemble. The reason of this "privileged position" lay on the amount of generous subsidies that these estates granted to the monarch and the certainty of their collection to back new debt (Tracy, 2002, pp. 293-301). Figure 1 illustrates that the reign of emperor Charles $V$ marked a turning point for the Castilian parliament in which it began to pass increasing pecuniary subsidies to the sovereign regularly, especially after the comunero revolt of 1520 1521. Despite this clash of authority, Charles V preserved the representative institution to support his foreign policy as a resource provider, which evinces that representation was a necessary concession for the good functioning of the state (Ertman, 1997, p. 112).

With the aim of giving a comparative measure regarding the Castilian subsidies, the servicio ordinario used to be estimated in circa 54 million maravedis prior to the reign of Charles V. The concession of 1504 of 102 million, however, was the result of a contribution plus and advance of the following one to cover the expenses of the war against France (Carretero Zamora, 1998, p. 17). Notwithstanding this initial royal achievement, any increase in the ordinary fiscal pressure, even a simple renewal, required the approval of the Cortes. This procedure, nonetheless, did not mean that Castilian Cortes were a restraining institution of royal expenditure (Álvarez Nogal and Chamley, 2014, p. 200; Stasavage, 2011, p. 147; Carande Thovar, 1987, vol. 2, p. 493). 


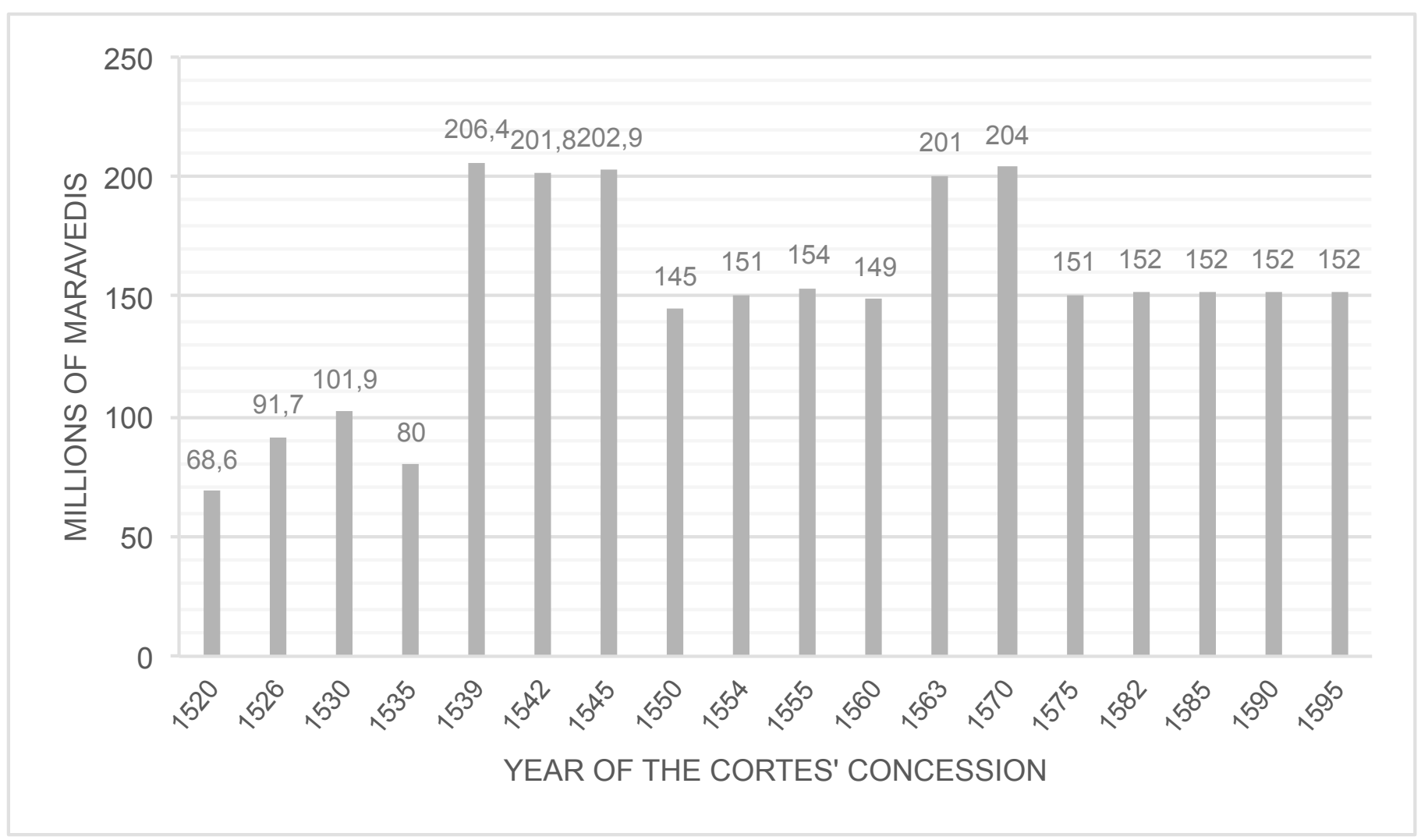

Figure 1. Servicios ordinarios of the Castilian Cortes (1520-1595) in millions of maravedis. Source: Carretero Zamora (1998, p. 21).

The apparent limitation to impose royal desires on the Castilian Cortes was not an obstacle to govern. The Cortes were a forum where the king and the main cities of Castile met together and discussed the problems of the kingdom, apart from passing the mentioned subsidies. The king, looking for his own benefit, always sought to keep a balance between the demands of his subjects and the subsidies they granted. Tracy has clearly defined the necessity for bargaining fiscal concessions that Hispanic sovereigns had to face in their multiple territories, such as Castile, the Habsburg Low Countries, and Naples (Tracy, 2002, pt. 3).

Understanding how the royal and local agendas converged is a question that still has much to offer. In the specific case of the Castilian Cortes, urban oligarchies managed the local tax collection of royal revenues, which granted them an important bargaining power. The role of these elites, who channelled funding to the monarch and assured his future incomes, provided him with steady cash and solvency to borrow from independent lenders in case of necessity. In this article, solvency must be understood as the possibility of the sovereign to create new sources of incomes and expenditure to make his finances sustainable (Drelichman and Voth, 2014, p. 106).

Apart from the fiscal perspective, the Cortes was an important social and economic institution. Whereas the sovereign tried to resolve his financial problems through modifications in the tax regime, urban representatives forwarded him their critics regarding to issues such as currency, salaries, certain offices, and much more. In other words, the Castilian cities debated with the monarch about transaction costs that affected directly to the economy of the kingdom. Transaction costs refer here to the economic costs of arranging and enforcing contracts over time and space, which includes information resources and involves the collaboration of formal and informal institutions (Dahlman, 1979, p. 148; North, 1997, p. 24). The bargaining between the sovereign and urban representatives, therefore, resulted in contractual agreements regarding the protection of property, the enforcement of contracts, and economic growth.

As a result of the research on this institutional bargaining, gone are the times when monarchies like the France, England, and the Hispanic Monarchy were considered "absolutist states". A classic example of this historiographical line is the work by the Marxist historian Anderson (Anderson, 1974, p. 15; Miller, 1990, chap. Introduction, especially, pp. 6-7; Wilson, 2000, chap. Introduction). From the 1980s onwards, multiple works have demonstrated that the Hispanic Monarchy, in particular, cannot be classified beyond a mere absolutist aspiration (Grafe, 2012, p. 9; Thompson, 2002; Jago, 1981, p. 326). Even American territories, legally bounded to Castilian jurisdiction, were self-administered. On this regard, the absence of representative institutions like Castilian Cortes has been considered as "a dilution, not a devolution of power". In other words, central royal institutions did not embody the authority overseas, but their colonial dependent institutions (Lynch, 1992, p. 73). A similar proposal is applicable to the European territories of the Hispanic Monarchy.

While the monarch had the legislative prerogative to enact new taxes and either raise or abolish the existing ones in certain parliaments, local elites hold the effective means of collection. Both the emperor Charles V and his son Philip II confronted these limitations to their demands, each of them in key turning points of their reigns (1536 and 1575 respectively) 
(Blockmans, 2002, p. 29; Fortea Pérez, 1990, p. 221). The question of absolutism was not a matter of authority but effective power. Hispanic sovereigns were subjected to grant concessions and mercies in exchange for collaboration at local level.

The institutional sociologist Thomas Ertman already emphasised this collaboration in his work about the role of local governments, representative assemblies, and the rulers' access to resources in the shaping of modern states (Ertman, 1997, pp. 317-319). In this sense, Ertman remarked the viability of decentralised states, since local elites were the actual mangers of territorial resources. As a result of his approach, the definition of "state" widened to include urban elites and their institutions. Going a step further, Braddick considered the "state" as a coordinated network of territorially bounded offices exercising political power, thus stressing the role of local elites in its development (Braddick, 2000, p. 19).

In this context of continuous negotiation with local elites, the thesis of the predatory absolutist state, which instinctively seeks to extract the maximum revenue, is simply unsustainable. Recent research has stressed that the early modern Hispanic Monarchy did not fit in this model since its levels of coercion were low compared to other early modern states of the region, such as France or England. The protection of property from private theft and public predation was relatively respected, whereas coercive means such as forced loans, depreciations, and monopolies were exceptional (Irigoin and Grafe, 2013, pp. 202-213).

The observance of the norms and rules of his unwritten pact with local elites by the Hispanic sovereign created a credible commitment, which economic historians have traditionally linked to economic growth. The concept of credible commitment was popularised by the classic work by North and Weingast of 1989, which stressed the requirement of two elements to occur: a precedent of "responsible behaviour" from the rulers and constraining tools to make them obey the rules (North and Weingast, 1989, p. 803; Coffman and Neal, 2013, p. 1).

Their conclusion is not misleading because the collaboration of local elites to raise taxes and channel them to royal treasuries was not an easy task, unless those groups of power had a private interest on that mechanic. Recent models of state-building are emphasising this same point. Grafe and Irigoin, for example, have suggested that the Spanish colonial empire was based on a stakeholder model in which local elites benefited from the correct functioning of the state administration (Grafe and Irigoin, 2012). In other words, local powerholders were part of the state administration.

Therefore, rulers and subjects played a decisive role in the process of state formation. The recent concept of "empowering interactions", which refers to the communicative situation that results from the convergence of the interests of state representatives and local elites, illustrates this process (Blockmans et al., 2009, pp. 25-27). This collaboration and its mutual benefits was clearer during exogeneous and endogenous threats, when there was a need for mobilising resources at local level (Besley and Persson, 2009, p. 1240; Tilly, 1990). The multiple wars and domestic conflicts in which the Hispanic Monarchy got involved in the early modern period have drawn the attention of scholars in that sense (Glete, 2002, p. chapter 3, especially, p. 121; Torres Sánchez, 2007). Notwithstanding the evident role of warfare in the development of states, its overuse shadow other "state shapers" (Boucoyannis, 2010).
However, the study of the relationship between conflict and states has resulted in promising works on the model of "contractor state", which have moved the focus to private military entrepreneurs together with their networks, thus incorporating those non-state people into the state apparatus (Maréchaux, 2017; Torres Sánchez, 2016; Parrott, 2012). The importance of non-military actors and their role as state-builders, nonetheless, has drawn less attention from scholars. Economic historians use to dilute the agency of financiers in macro-economic analysis about the finances of Hispanic sovereigns, which results in few individual studies on the way the relationship of these individuals with state administrations and military providers worked (Sanz Ayán, 2015). The following section introduce the reader to the conditions in which is possible to analyse the role of financial entrepreneurs as state-builders in relation with their clientele, especially regarding their mutual collaboration with the royal administration to preserve the state apparatus.

\section{The inheritance of Charles $\mathrm{V}$ and the Castilian economic rhythm}

Since mid-1554, the widow princess of Portugal, Joanna of Austria, assumed the regency of Castile while her brother the prince Philip departed on $13^{\text {th }}$ July to England to marry with the English queen Mary Tudor (Charles V, 1554). Two years later, the emperor Charles $V$ abdicated in favour of his son Philip the rule of the Iberian kingdoms, Naples, Sicily and the Habsburg Low Countries. The Council of State acknowledged the transmission of powers in Castile by March 1556 (Council of State, 1556). Princess Joanna remained in Castile administering a very unstable treasury, while the new king Philip II began to demand subsidies to fund a simultaneous war against France, the Papal States, and the Ottoman Empire (Parker, 2014, p. 50). Philip II had succeeded to his father's wealthiest thrones at the price of inheriting large-scale international commitments and conflicts. The classic study of Rodriguez-Salgado about this dynastic transition is still one of the best approaches to this period (Rodriguez-Salgado, 1988).

The hostile legacy resulted problematic for a royal treasury that was unable to set enough funds for all the fronts in the ongoing war. Some scholars have labelled this dramatic situation of royal finances as "a bankruptcy of succession", a concept still discussed in academia. Carlos Morales coined this concept in the Spanish-speaking literature about this topic. However, as he explains in his later works, Philip II did not decree a bankruptcy, but a debt consolidation. In this sense, he attaches to the main argument of the already mentioned Rodriguez-Salgado's study (Carlos Morales, 2006, p. 331).

Since Hispanic and French monarchies experienced similar financial problems, they agreed a truce on $5^{\text {th }}$ February 1556 in Vaucelles. Notwithstanding the ceasefire, an armed peace followed until January 1557. During the peace time, the fiscal balance of Philip II showed an increasingly worrying deficit. Figure 1 provides a glimpse into the evolution of marginal funds that the monarch received to satisfy its short-term debt (grey line). Although the ordinary incomes of the Hispanic sovereigns remained stable from 1552 to 1559 , Charles V and Philip II were progressively less able of servicing their debts on time and interest accrued dangerously. Their long-term debt (consolidated debt) left small margin to pay short-term debt (floating debt), especially when Philip consolidated the 


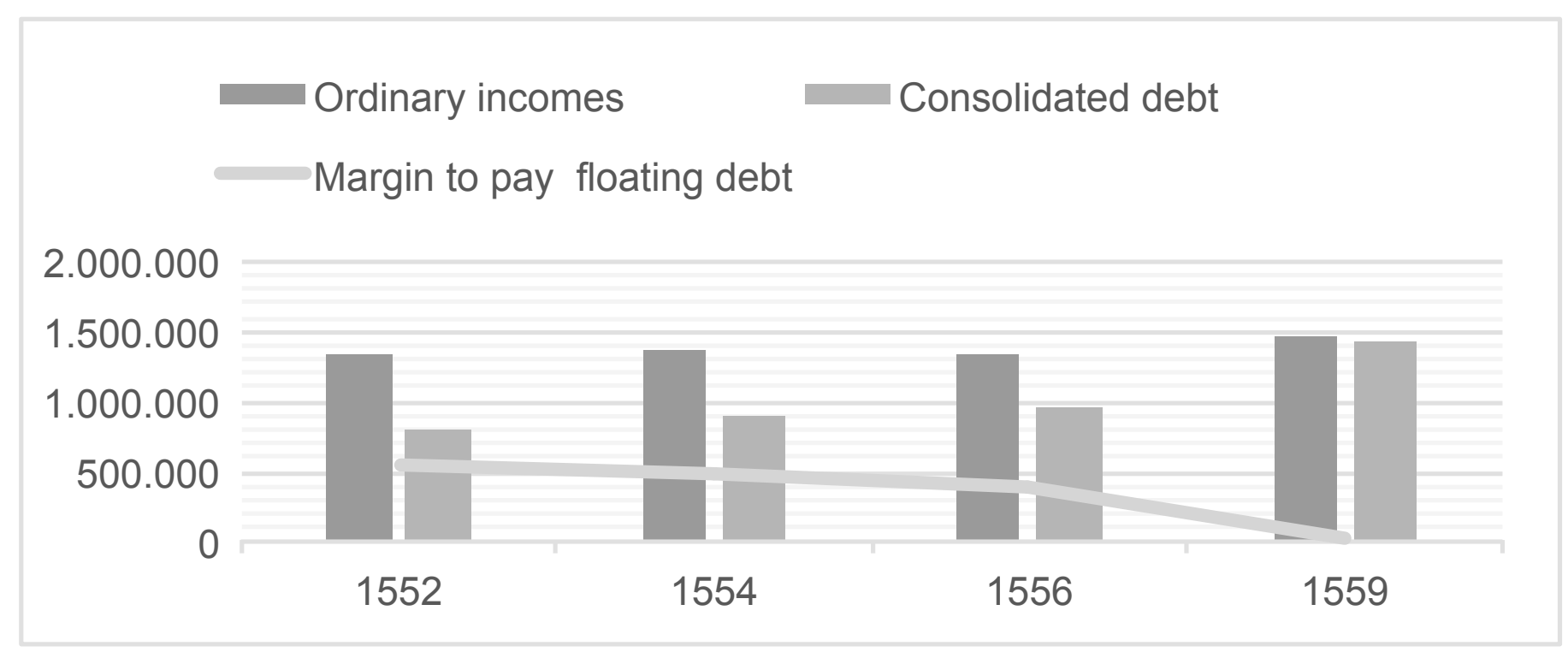

Figure 2. Evolution of the financial statement of Charles V and Philip II between 1552 and 1559 (in ducats). Source: Ulloa, La Hacienda Real de Castilla en tiempos de Felipe II, p. 130.

latter in 1557. This event obliged to seek an increase in the ordinary incomes to match the expenses.

Before the situation reached that turning point, regent Joanna wrote to Philip II in June 1556 warning that only his return to Castile could save the situation (Joanna of Austria, 1556). Joanna wanted to summon the Cortes of Castile and negotiate the renewal of traditional subsidies and a fiscal increase. In the last years, scholars have tended to focus on the ability of the Castilian Cortes to limit the royal spending and borrowing; hence, negotiation was the common pattern (Álvarez Nogal and Chamley, 2016; Carretero Zamora, 2010; Jeon, 2014; Yun-Casalilla and O'Brien, 2012). The final motivation of Joanna was to increase the royal borrowing ceiling that was limited by the fiscal burden on the kingdom. Despite of the urgency of these agreements, they were not passed until 1559. In the meantime, the king faced the penalty of Genoese lenders, who refused to keep lending until Philip II fulfilled his liabilities (Gómez Suárez de Figueroa, 1556).

After several failed strategies to raise more money, Philip II ordered a financial reorganisation to increase his borrowing ceiling in the last months of 1556 . The plan consisted in the creation of a system of factores reales, who would be deployed in the main financial and commercial centres of western Europe under Hispanic control or influence: Antwerp, Valladolid, and Genoa. The motivations behind this novelty seems to have been the outbreak of the war in Italy against Pope Paul IV, the retirement of Charles V to Castile, and the need of diminishing the influence of merchant-bankers in royal finances (Carlos Morales, 2008, pp. 36-37; Hernández Esteve, 2003, p. 247; Rodriguez-Salgado, 1988, p. 236).

The new system centralised the finances of the king in the hands of four experimented businessmen, though only Fernán López del Campo became the factor general. His role obliged him to move in Castile, where he arrived in October 1556 with instructions to manage all royal finances and negotiate the military supply for the Council of War. Thanks to the extensive work of Hernández Esteve on the accounts of the Factoría General and the person of López del Campo, we know that the main instruction of López del Campo was to restore the financial reputation of Philip II (Hernández Esteve, 2013, pp. 208$214 ; 2010 ; 1984)$. In other words, all the powers that López del Campo received were intended to simulate the sustainability of royal debts and an apparent solvency that the monarch lacked.

Despite of some resistance in the regent government, López del Campo analysed the general situation and reported it to Philip II on $1^{\text {st }}$ February 1557 (Fernán López del Campo, 1557). The factor general described that Castilian commerce was diminishing because of the royal decrees of November 1551 (prohibition on the issuance of bills of exchange within Castile), December 1555 (setting of the interest rates in external exchanges) and March 1556 (prohibition of exchanges within the Iberian Peninsula). These three edicts were the result of protectionist policies that sought to prevent cash from leaving the economic Castilian circuit, besides lowering interest rates for new loans (Carlos Morales, 2008, p. 35). However, these decrees were forcing merchants to borrow from speculators at very high interest rates. According to the report of the factor general, the royal policy was detrimental for economic growth. Since that policy was implemented by formal institutions, this episode contradicts North's theory regarding the need of formal institutions rather than informal ones in large states where transaction costs were higher (Keefer and Shirley, 2000, pp. 96-97; North, 1990, pp. 120-121).

While the edicts that regulated the financial market were not banned, wrote López del Campo, the businessmen who had moved to operate in Portugal, France, Italy or Flanders might never return to Castile (Fernán López del Campo, 1557) $)^{1}$. The resultant diversion of capital was detrimental for the economic circuits, especially to merchants who hardly could find funding in the domestic market. The royal decrees were, nonetheless, a political movement hardly dispensable

\footnotetext{
1 “[...] it will be difficult to take them (from the other states abovementioned)
} and bring them back (to Castile)". 
since they were intended to fight against usury practices, besides their financial goals. The spiritual characteristics of these decrees is relevant in this episode because the regent government and the assembly of the Castilian clergy (autumn 1555 - spring 1556) debated about the ecclesiastical contribution to Philip II.

At this meeting, the loyalty of the Castilian clergy to Philip II or Pope Paul IV was undecided. Any action against the moral principles of the clergy, such as the abolition of the edicts, could mean a loss of influence in this estate. Nonetheless, more work is necessary regarding this connection (Perrone, 2008, chap. 7). Apart from reporting, López del Campo proposed a less "state"-controlled financial market through a masterplan based on restoring the domestic and external money transfers, except for Portugal due to a currency issue. The deregulation of the financial market would attract businessmen to Castile again and force Portugal to restore its previous currency values.

Simultaneously, López del Campo presented a joint project to reorganise the royal debt. It suggested to stop payments on the short-term debt of the king, which charged the highest interests, and consolidate that debt through juros al quitar (long-term royal debt bonds) at $5 \%$ of annual interest. With this financial tactic, Philip II could recover the incomes earmarked to pay short-term debt, thus enabling him to borrow again. Foreseeing the general uneasiness of royal financiers because of the financial shock, López del Campo suggested to start redeeming those juros as soon as possible to keep the royal reputation high. Finally, although Philip II sent the order to the regency government on $17^{\text {th }}$ April 1557, it was not enforced until the $10^{\text {th }}$ June of that year because of the resistance of Joanna (Carlos Morales, 2016, p. 82; Rodriguez-Salgado, 1988; Martín, 1968, pp. 114-118; Philip II, 1557).

When the news about the debt consolidation arrived in Toledo (Castile), the problem became a European concern. Several businessmen dispatched letters to Lyon, Germany and Genoa reporting about the royal decision and enquiring how they should react. Many Genoese lending houses could declare bankrupt in the following fairs of payments if the sovereign did not rectify his decision or reach individual agreements. Notwithstanding the initial shock, Genoese financiers sought to reach good terms with Philip II providing him with new financial services in the following months. Among the conditions these lenders negotiated with royal representatives, they demanded to be paid in cash rather than to obtain debt shares earmarked to future royal rents. In other words, they demanded steady money with which satisfying their own creditors (AGS, CJH, leg. 34, 56, 1558; AGS, CJH, leg. 34, 63, 1558; Council of Finances, 1557)2.

This situation changed on $22^{\text {nd }}$ May 1558 , when a prominent Genoese lender called Nicolao de Grimaldo signed a loan contract with López del Campo. Romano seems to have mistaken the date of the contract as he claims it was signed on the 12th May, while diverse sources confirm it was agreed ten days

\footnotetext{
2 There are some examples from the asiento with Daniel Spinola to Costantin Gentil and the Centurione consortium between July 1557 and March 1558. All their reimbursements were agreed in cash.
}

later (Romano, 1949, p. 243; Fernán López del Campo, 1558). The document shows that the king accepted to reimburse his past debts through juros al quitar with higher interest rates than those offered in the consolidation of debt. This practice benefited the royal treasury because it had not to search liquidity immediately to fulfil its obligations ${ }^{3}$. Indeed, other financiers such as Costantin Gentil, the representative of the Genoese consortium of the Centurione family, imitated this strategy in the following months.

The lenders sold in the secondary market of debt their juros al quitar to third parties, with which they obtained liquidity to keep doing businesses. The resale of juros was a financial strategy that is currently drawing the attention of scholars (Álvarez Nogal and Chamley, 2018; Sánchez Camacho, 2018). However, many of those juros were earmarked to a new tax that charged the exports of wool in Castile, a relation that opens a large field of research in which Genoese high financiers and Castilian wool merchants were more interconnected than could be expected at first sight.

\section{The consolidation of royal short-term debt and the new tax on exported wool: connecting people}

In the decree of $17^{\text {th }}$ April 1557, Philip II also demanded the enactment of a new tax on exported wool in Castile, which was delayed for a year until the $30^{\text {th }}$ April 1558 (González Presbítero, 1829, vol. 2, p. 112). The new fiscal imposition was part of the masterplan that López del Campo proposed in February 1557 to Philip II abovementioned. If the exporter was Castilian, the new tariff charged one ducat per sack of wool travelling from Castile to Flanders and two ducats if the wool was exported to France or Italy. Instead, the duty doubled if the wool exporter or his associates were foreigner. Apart from the tariff, every destination had a different way of weighting the wool, which varied the value of the final duty. The classic study by Lapeyre on this topic is still valid and valuable (Lapeyre, 1981, chap. IV).

Table 1 demonstrates that exporting to Flanders, in the Habsburg Low Countries, was theoretically much more profitable than to other places. This economic policy sought to encourage domestic exports and divert the flux of wool towards Flanders, which could also tax the entry of wool shipments. The factor general foresaw that the fiscal novelties could create unrest among the main groups of merchants and, therefore, local elites with influence in the Castilian Cortes. He was not mistaken. In the IX petition of the 1558 Cortes, urban deputies demanded the abolition of the tax (Colmeiro, 1863, p. 735). They claimed that it was damaging for the kingdom while also complaining about the aggression that the new tax meant for tax-exempted social groups ( $\mathrm{ca}$ balleros e hijosdalgo). In other words, local elites showed to be more worried about themselves than those whom their deputies represented.

\footnotetext{
${ }^{3}$ There was a previous asiento signed with just one Genoese financier Daniel Spinola, in July 1557 that included old debts, but these would be repaid in cash. The difference between this contract and Nicolao's lies in that the latter had to market juros to recover those old debts.
} 


\section{Table 1}

Comparison of the costs to export 100 arrobas of wool being Castilian or foreigner.

\begin{tabular}{llll}
$\begin{array}{c}\text { Arrobas } \\
\text { to export }\end{array}$ & Destination & $\begin{array}{c}\text { Number } \\
\text { of sacks }\end{array}$ & \multicolumn{1}{c}{ Duty } \\
\hline 100 (Castilian) & Flanders & 12 (sacks of & 12 ducats \\
100 (foreigner) & & 8.5 arrobas) & 24 ducats \\
\hline 100 (Castilian) & France, Italy, & 10 (sacks of & 20 ducats \\
100 (foreigner) & others & 10 arrobas) & 40 ducats \\
\hline
\end{tabular}

Source: Henri Lapeyre, El comercio exterior de Castilla a través de las aduanas de Felipe II, p. 171.

To counteract any resistance, Philip II negotiated with the two leading poles affected by the tax, Burgos and Seville. The monarch offered the abolition of an old decree that obliged wool exporters to bring clothes and lines back to Castile from their businesses, a law that limited their commercial freedom and conditioned their operations in France. The Castilian merchant community had a long-term experience in that monarchy. In the fifteenth century, for example, businessmen from Burgos used to operate in important commercial hubs such as Rouen, Nantes, La Rochelle, and Toulouse to import fine clothes, wine, naval supplies, or pastel. They also used these cities as intermediary points with the northern trade (Casado Alonso, 2014, p. 284). Notwithstanding the apparent preference for Flanders, Lapeyre discovered that some cargoes went to Flanders to then return to Rouen because this long round trip was cheaper than paying the duty exporting from Castile to France directly (Lapeyre, 1981, p. 185).

Therefore, the abolition of the law to import clothes was a convenient retribution to the business communities in exchange of their collaboration with the new tax on wool exports. The communication and empowering interaction between formal and informal institutions, therefore, proved to be essential in the correct functioning of the Hispanic Monarchy. After all, the new duty promoted the exports to the Habsburgs Low Countries, which simultaneously encouraged the imports of refined textiles from that region instead of France. Apart from the intended commercial reorganisation that directly attached the French industry, the new tax should also provide funds to reimburse the outstanding debts of the monarch. The factor general had made clear this point in his letter to Philip II (Fernán López del Campo, 1557).

The literature about the new right is abundant and contains rich information about its peculiarities and evolution (Basas Fernández, 1963, p. 253, 1961, pp. 329-330; Lapeyre, 1981, pp. 165-209; 1974, pp. 221-239; Ulloa, 1986, pp. 327-340). The tax was implemented over one of the most profitable business of the Hispanic Monarchy. The wool trade had its headquarters in Castile, where flocks of sheep were bred, moved, and sheared. Most of the fleeces obtained after shearing were exported to the main western European manufacture centres (the Habsburg Low Countries and Italy, mainly Genoa and the Duchy of Florence) rather than used by the Castilian industry. Exporting wool was, nonetheless, an expensive and long process that demanded of high investments from merchants. Exporters used to purchase the fleeces to the shepherds about one year beforehand, which especially increased transaction costs related to information and contract enforcement. Afterwards, they could wash the wool in specialised places dispersed in Castile, an operation that was expensive though generated higher profits in the international market (Girón Pascual, 2011). Once the wool was ready, it was transported towards the main ports of Castile, which could be organised in four districts: North (Bilbao and the Cuatro Villas), East (Cartagena, Yecla, and Murcia), South (Seville and Malaga), and Portugal.

When the new tax on exported wool was enforced, the royal administration deployed tolls in those three districts and began to collect the duties as soon as 1558 . However, instead of keeping the earnings from the tax, the king had already decreed to forward most of them to Nicolao de Grimaldo, the Genoese financier who accepted to be paid in juros al quitar rather than in cash (Figure 2). Since its birth, the money collected through the new fiscal imposition was intended to start repaying old debts to royal lenders. This strategy aimed to recover the royal reputation as solvent borrower, since Philip II had been able to create new sources of trustworthy and regular revenue to back new debt.

The procedure of repaying them was complex. Financiers like Grimaldo sold the juros al quitar, which the monarch issued for them in each new asiento since May 1558, to Castilian and foreign investors. This strategy helped to diversify risks in case the royal rents earmarked to pay the interest of those juros resulted not profitable. This resale also provided with liquidity to the Genoese lender as he acted as intermediary between the king and his subjects in the acquisition of those juros. The Genoese financiers liked to keep some juros for themselves as long-term investments that backed their solvency. Finally, those investors who purchased juros al quitar received their interest individually each year. Fortunately, a list of the clients of Nicolao de Grimaldo in 1559 is available at the General Archive of Simancas (AGS, CJH, leg. 35, 23, 1559).

Interestingly, Genoese financiers such as Nicolao de Grimaldo and Costantin Gentil -real architects of the new financial structure- took care of keeping the wool market alive. If earlier in this article it has been pointed that the Castilian commercial activity was declining because of the royal edicts of the 1550s, the lending services of Genoese high financiers to Castilian wool exporters helped to keep the market of capital alive, notwithstanding its previous damaged state. In other words, informal institutions such as the Genoese lending community solved the problems that formal institutions created and were causing an economic setback. Were informal institutions viable in large states? Figure 3 shows the evolution of the tax collection until 1598, highlighting a pronounced decline after the promulgation of the new fiscal imposition in 1558 until January 1563 and June 1566, when the king increased the tariffs alleging the need of counteract frauds. Whereas informal institutions helped to keep the wool market alive offering financial services to Castilian merchants, the royal administration (formal institution) collected less revenue until it applied coercive means. The clash between the interests of both groups was evident at the Castilian Cortes of 1563, when urban representatives asked to abolish the new increase in the tariff to export wool and return to the initial fiscal policy of the tax (Diputados, 1861, p. 373). Although the sovereign rejected their petition, this episode reflects the constant bargain between two economic models: one based on informal institutions that preserved economic activity; and another based on regulations im- 


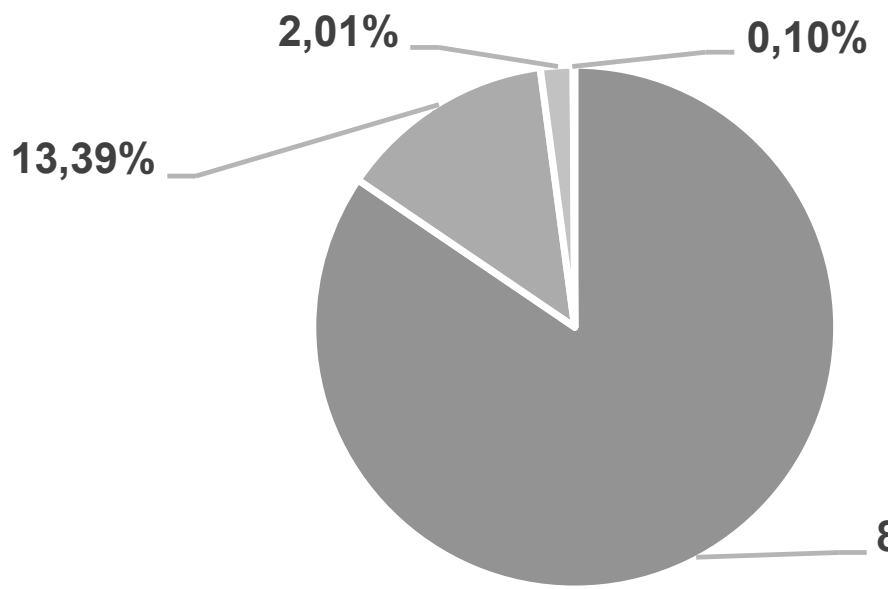

- Nicolao de Grimaldo

- Other expenses

- López del Campo, general factor

84,50\% Diego de Guzmán, notary

Figure 3. Beneficiaries of the new tax on exported wool (1558).

Source: AGS, CJH, 35, 172.

posed by formal institutions that sought to maximise revenue at the expense of economic growth.

The evolution of this trade was not the same in the Atlantic than in the Mediterranean. Northern exports were in serious decline because of the rebellion in the Habsburg Low Countries and the Anglo-Hispanic maritime conflict, in which the French civil war played an important role. Whereas the French market absorbed part of the Flemish imports of Castilian wool, it was not enough and the importance of Burgos in the northern wool exports practically vanished by the end of the century.

However, this decline linked to military and political events was simply a transformation. Burgos and its neighbouring regions, former core of the northern commerce, found new opportunities trading eastwards to Italy. In effect, the Castilian commercial oligarchies partially displaced to the Genoese wool exporters in the Mediterranean area, which was simultaneous to the concentration of exports in fewer hands than at the initial years of the new tax. According to Lapeyre, "the gravity centre of Castile had moved southwards", a tendency recently confirmed for the last quarter of the century (Lapeyre, 1981, pp. 184-191; Girón Pascual, 2013, p. 119). This shift means that informal institutions were dynamic, but also that a decision of a formal institution, such as the enactment of the tax, could transform the former in unexpected ways.

Back to the beginning of the timeline, the role of Genoese financiers such as Nicolao de Grimaldo or Costantin Gentil funding Castilian wool merchants since 1558 is remarkable. The analysis of a series of data from 1558 to 1560 sheds light about this issue and allows to create connections among royal lenders and Castilian merchants beyond the separated studies

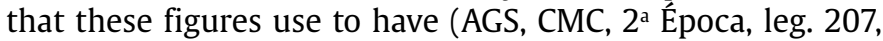
n.d.; AGS, EMR, leg. 440, n.d.; AGS, EMR, leg. 443, n.d.). For example, graph 1 illustrates the multiple connections that existed among wool merchants and lenders in 1559. Many businessmen did not have many ties and are represented practically isolated cases. Apart from these cases, whose study is left to further research, it is possible to identify up to five main groups interconnecting five people together at least.
Within this "big league", networks A and B show a higher degree of clustering that emphasise the role of key lenders interweaving multiple actors. Whereas group A is clearly marked by its predominant Genoese character, group B presents a total absence of non-Castilian businessmen, either merchants or lenders. The first network, nonetheless, allowed that some Burgos merchants took part in their syndicated operations. This permeable commercial strategy reinforces the traditional literature claiming that Genoese lenders financed Castilian merchants (Lorenzo Sanz, 1986, p. 25). This research emphasise that these ties did not collapse during the immediate consequences of the royal financial crisis of 1557 and the new fiscal imposition on exported wool.

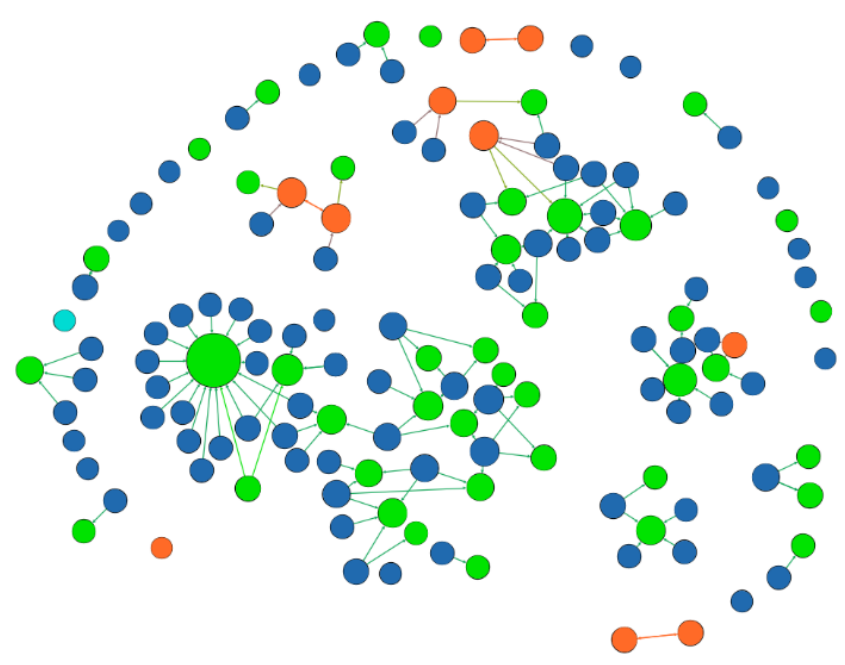

Graph 1. Businessmen involved in the duty on exported wool (1559). Grouped by colours: blue (merchant), green (lender) and red (merchantlender). Sized by number of connections.

Source: AGS, EMR, 440. 


\subsection{0 .000}

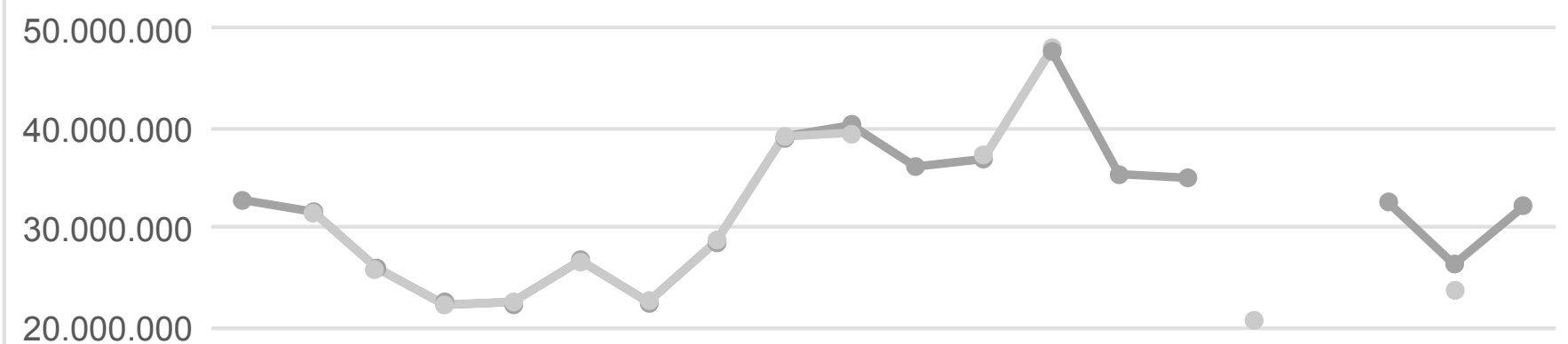

10.000 .000

0

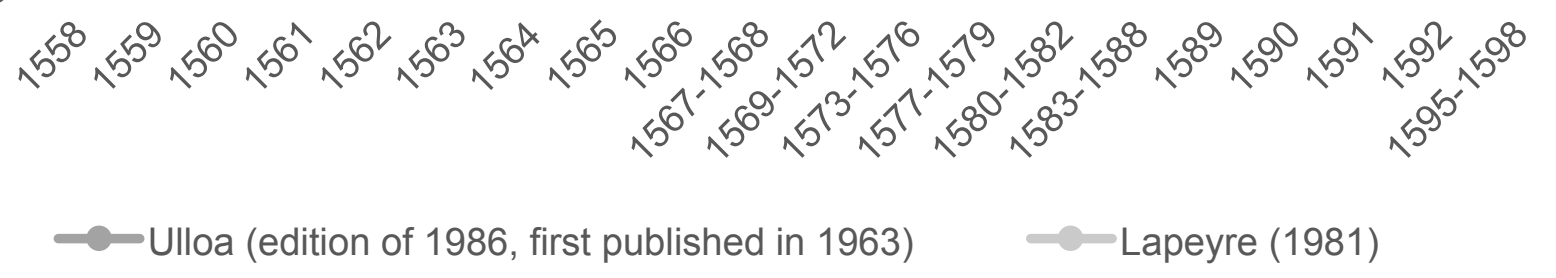

Figure 4. Incomes of the new tax on exported wool (1558-1598).

Sources: Modesto Ulloa. La Hacienda de Felipe II, p. 334 and Lapeyre In maravedis, El comercio exterior de Castilla a través de las aduanas de Felipe II, p. 195. Note: the intervals of years reflect the annual average of the tax in that period. Ulloa and Lapeyre differ in some of their findings. For the periods $1569-1572$ and 1580-1582, Lapeyre only registers the incomes from the northern coast, which renders the comparison to Ulloa's estimation for those years impossible.

If the Genoese financiers stopped funding Castilian wool merchants, these would have probably bankrupted because of the new tax on exported wool, which reduced their competitivity before foreign businessmen. The funding of Genoese financiers became then an important tool for wool exporters, who accepted the decrease of their earnings because of the necessary financial backing. In addition, it is possible to detect that the wool exporting companies had a longer duration than before, and they were based on ties of kinship and reputation. For example, Nicolao de Grimaldo funded a Burgos company led by three of the most prominent merchants of the city that had relatives in the local council (AGS, EMR, leg. 440, n.d.).

The involvement of Genoese high financiers in the exports of Castilian wool results promising. Scholars have often focused on the necessity that the Genoese lending community had to export the profits of funding royal enterprises (Ruiz Martín, 1990, p. 137). The main way of forwarding the benefits back to Genoa consisted in licencias de saca, a royal permission to export precious metal out of the Hispanic borders. Castilian legislation from the thirteenth century banned the practice, a political position that remained practically intact until the reigns of Charles V and Philip II. While the prohibition was active, financiers had to purchase commodities and sell them outside the Hispanic Monarchy to thus collect their profits in precious metal (Marcos Martín, 2006, p. 347). In few words, the royal legislation prevented the money in circulation from exiting the realm and promoted the domestic economic circuits.
The financial necessities of Charles V and Philip II, however, obliged them to temporarily tolerate the exports of precious metal in exchange of financial services. In the years of this study, particulars could export precious metals from 1552 until 1560. The resumption of legal exports meant that lenders like the Genoese Nicolao de Grimaldo and Costantin Gentil had no need to invest in commodities to export the profits of their financial services to the monarch. Therefore, the participation of Grimaldo and Gentil in the exports of Castilian wool through the funding of native merchants reflects the necessity of making viable that commerce. The goal of those lenders was to support the commercial activities to make possible the collection of the reimbursements of their asientos after the consolidation of debt in 1557.

In the long-term, investing in the wool trade was a profitable business still in the 1570s. When Philip II declared another suspension of payments and banned any exportation of bullion from particulars in 1575 , for example, the Genoese financiers reinvested their profits in the wool market to resale the product to thus obtain cash in foreign markets (Phillips and Phillips Jr., 1997, p. 256). However, the situation was different to that of 1559 because the Genoese lending community purchased wool rather than funding Castilian merchants. In this sense, the reaction to the problem of 1575 suggests a necessity to transport the profits back to Genoa rather than making the royal debts sustainable like in 1559 .

Although the causes of this change of strategy were multiple, one of them might be considered as principal. The war 
against the rebels in the Habsburg Low Countries had increased the prices of insurances and therefore the prices of fleeces in the market, which made this product less competitive than other alternatives such as the English wool. As the war continued and worsened with the fall of key ports in the English Channel before the rebels, the principal flow of wool trade was diverted to Italy, which simply could not absorb it entirely. The seventeenth century witnessed the slow downfall of this very profitable business that had achieved its golden epoch in the mid-sixteenth century (Bilbao Bilbao, 1983).

\section{Conclusions: early modern state-building process through the convergence of private agendas among non-state actors}

The main goal of this article has consisted in highlighting the interaction of independent entrepreneurs among one another and with the jurisdictionally highest institution of the Hispanic Monarchy to illustrate their agency in the state-building process. The outcomes of the research have confirmed that the stakeholder model of state might be promising to explain the resilience of the Hispanic Monarchy in the early modern period. Three perspectives, framed in a context of institutional analysis, help to explain this conclusion: fiscal, financial, and political.

First, the Hispanic Monarchy was not an absolute state from the fiscal point of view. Effective power to raise funds, rather than authority, was constantly bargained with formal and informal institutions alike. Among the former, the fiscal concessions of representative assemblies like the Castilian Cortes put a ceiling to the borrowing capacity of Hispanic monarchs. Regarding informal institutions, the collaboration of local business elites from Burgos and Seville to enact the new tax on wool exports was necessary. As it has been stressed in the fourth section, such bargaining was not an idea of the monarch or any other high rank royal official. Instead, a former merchant and financier, the factor general López del Campo, was the author of the strategy. In other words, a private entrepreneur at the royal service drafted a masterplan to overcome the financial difficulties of the Hispanic central administration minimising coercive means and opting for negotiating rather than employ more predatory strategies.

From the financial point of view, Genoese financiers and Castilian local elites joined efforts to sustain the royal administration that fuelled their private economic interests and ensured the protection of their properties. Informal institutions in the form of business networks (ex. Genoese, Burgos, Sevillian...) collaborated with the Factoría General, a formal institution, to sustain the monarchy. Without the help of private entrepreneurs, the factor real would have failed to provide resources at lower transaction costs. As a result of this strategy of converging interests, which complements the thesis of the decentralised character of the Hispanic Monarchy, formal and informal institutions were practically identical.

The funded debt of the sovereign was the catalyser of the agendas of all those entrepreneurs who benefited from the enactment of the new right on wool exports. Without the cash injections of Castilian private investors purchasing juros and the resort of Castilian businessmen to the Genoese financial intermediation, the survival of formal and informal institutions was at risk. Funded debt was, therefore, a convenient tool that grouped together public and private agendas to the extent of avoiding a coordination failure. It is not possible, however, to discern whether the convergence of public and private agendas analysed in this study was sufficient to promote economic growth in the long-term. At least, the Castilian wool trade survived for another half a century, though its fate was linked to the political stability of Western Europe rather than new taxes.

Finally, war remains as a repetitive pattern present at the development of institutions such as the Factoría General or in the evolution of the Genoese lending strategies. However, the external threat might be a distractor element in the process of state formation, at least applied to this study. Whereas it is true that the Habsburg-Valois conflict drained the resources of both monarchies and triggered the institutional and financial reforms in the Hispanic Monarchy examined, it is equally right that royal demands of resources to Castile simply magnified the existing domestic problems inhered from the reign of Charles V. Conflict was always there, both external (war) and internal (institutional conflict), and therefore it must be considered as a contextual trigger rather than an actor with an agenda. The convergence of private interests of non-state actors, such as the private entrepreneurs analysed in this article, and state servants had a much larger influence in the state development than any conflict.

\section{Acknowledgments}

This article has been awarded with the Ramón Carande 2020 prize, sponsored by the Asociación Española de Historia Económica. I would like to thank their time invested in considering my proposal and the opportunity to publish this article in their academic journal Investigaciones de Historia Económica. I also want to thank the editorial board and external reviewers for their advice and constructive comments on the contents of this paper, which undoubtedly have improved its academic quality.

\section{Key}

AGS: Archivo General de Simancas. CJH: Consejo y Juntas de Hacienda. CMC: Contaduría Mayor de Cuentas. EMR: Escribanía Mayor de Rentas.

EST: Estado.

Leg.: Legajo.

\section{Archival sources}

AGS, CJH, leg. 34, 56, 1558.

AGS, CJH, leg. 34, 63, 1558.

AGS, CJH, leg. 35, 23: Lanas de Nicolao de Grimaldo, 1559.

AGS, CMC, 2 a Época, leg. 207, n.d.

AGS, EMR, leg. 440, n.d.

AGS, EMR, leg. 443, n.d.

Charles V, 1554. AGS, EST, leg. 481, 36.

Council of Finances, 1557. AGS, CJH, leg. 30, 28.

Council of State, 1556. AGS, EST, leg. 112, 70.

Fernán López del Campo, 1558. AGS, EST, leg. 129, 233.

Fernán López del Campo, 1557. AGS, EST, leg. 121, 62.

Gómez Suárez de Figueroa, 1556. AGS, EST, 1385, 82.

Joanna of Austria, 1556. AGS, EST, leg. 114, 80.

Philip II, 1557. AGS, EST, leg. 810, 85. 


\section{Bibliography}

Álvarez Nogal, C. and Chamley, C., 2016. Philip II against the cortes and the credit freeze of 1575-1577. Revista de Historia Económica, 34, 351-382.

Álvarez Nogal, C. and Chamley, C., 2014. Debt policy under constraints: Philip II, the Cortes, and Genoese bankers. Econ. Hist. Rev. 67, 192-213.

Álvarez Nogal, C. and Chamley, C., 2018. Refinancing short-term debt with a fixed monthly interest rate into funded juros under Philip II: an asiento with the Maluenda brothers. Economic History Review, 71, 1100-1117.

Anderson, P., 1974. Lineages of the Absolutist State, Verso World History Series. NLB.

Basas Fernández, M., 1963. El Consulado de Burgos en el siglo xvı. Diputación Provincial de Burgos, Burgos.

Basas Fernández, M., 1961. Burgos en el comercio lanero del siglo xvi. Moneda Crédito 77, 37-68.

Besley, T. and Persson, T., 2009. The Origins of State Capacity: Property Rights, Taxation, and Politics. American Economic Review, 99, 1218-1244. https://doi.org/10.1257/aer.99.4.1218

Bilbao Bilbao, L. M., 1983. Exportación y comercialización de lanas de Castilla durante el siglo xVII (1610-1720) In: El pasado histórico de Castilla y León: Actas del I Congreso de Historia de Castilla y León celebrado en Valladolid, del 1 al 4 de diciembre de 1982, pp. 225-243.

Blockmans, W. P., 2002. Emperor Charles V, 1500-1558. Arnold, London.

Blockmans, W. P., Holenstein, A. and Mathieu, J. (eds.), 2009. Empowering interactions: political cultures and the emergence of the state in Europe, 13001900. Ashgate, Farnham, Surrey, England; Burlington, VT.

Boucoyannis, D. A., 2010. War: The Tyranny of a Concept (SSRN Scholarly Paper No. ID 1644116). Social Science Research Network, Rochester, NY.

Braddick, M. J., 2000. State formation in early modern England, c. 1550-1700. Cambridge University Press, Cambridge [England]; New York.

Carande Thovar, R., 1987. Carlos V y sus banqueros. Crítica, Barcelona.

Carlos Morales, C. J. de, 2016. El precio del dinero dinástico: endeudamiento y crisis financieras en la España de los Austrias, 1557-1647. Vol. 1. Banco de España, Madrid.

Carlos Morales, C. J. de, 2008. Felipe II: el Imperio en bancarrota: la hacienda real de Castilla y los negocios financieros del rey prudente. Universidad Carlos III de Madrid, Madrid.

Carlos Morales, C. J. de, 2006. Felipe II y sus banqueros. In: Banca, Crédito y Capital. La Monarquía Hispánica y Los Antiguos Países Bajos (1505-1700). Fundación Carlos Amberes, Madrid, pp. 329-344.

Carretero Zamora, J. M., 2010. El Servicio de las Cortes de Castilla: una fuente para el estudio de la fiscalidad extraordinaria y del crédito en la Corona de Castilla (siglo xvI). Presented at the Fuentes para el estudio del negocio fiscal y financiero en los reinos hispánicos (siglos XIV-XvI), Instituto de Estudios Fiscales, Madrid, pp. 41-68.

Carretero Zamora, J. M., 1998. Los servicios de las Cortes de Castilla en el siglo xvi. Cuadernos de Historia Moderna, 185, 15-58.

Casado Alonso, H., 2014. Circuitos comerciales y flujos financieros en Castilla a fines de la Edad Media e inicios de la Modernidad. Presented at the Estados y mercados financieros en el occidente cristiano (siglos XIII- XvI): XLI Semana de Estudios Medievales, Estella, 15-18 de julio de 2014, Gobierno de Navarra, pp. 273-307.

Coffman, D. and Neal, L., 2013. Introduction. In: Questioning Credible Commitment: Perspectives on the Rise of Financial Capitalism, Macroeconomic Policy Making. Cambridge University Press, Cambridge, pp. 1-20.

Colmeiro, M., 1863. Cortes de los antiguos reinos de León y de Castilla. Real Academia de la Historia, Madrid.

Dahlman, C. J., 1979. The Problem of Externality. The Journal of Law and Economics, 22, 141-162.

Diputados, C. de los, 1861. Actas de las Cortes de Castilla, publicadas por acuerdo del Congreso de los Diputados a propuesta de su Comisión de Gobierno Interior. Imprenta Nacional, Madrid.

Drelichman, M. and Voth, H. J., 2014. Lending to the borrower from hell: debt, taxes, and default in the age of Philip II, The Princeton economic history of the Western world. Princeton University Press, Princeton.

Elliott, J. H., 1992. A Europe of Composite Monarchies. Past Present, 137 (1), 48-71.

Epstein, S. R., 2002. Freedom and Growth: the Rise of States and Markets in Europe, 1300-1750. Routledge.

Ertman, T., 1997. Birth of the leviathan: building states and regimes in medieval and early modern Europe. Cambridge University Press, Cambridge, UK; New York.

Fortea Pérez, J. I., 1990. Monarquía y cortes en la Corona de Castilla: las ciudades ante la política fiscal de Felipe II. Cortes de Castilla y León, Valladolid.
Girón Pascual, R. M., 2013. Las Indias de Génova: mercaderes genoveses en el reino de Granada durante la Edad Moderna (ss. XVI-XVIII). Universidad de Granada, Granada.

Girón Pascual, R. M., 2011. Los lavaderos de lana de Huéscar (Granada) y el comercio genoves en la edad moderna. In: Génova y La Monarquía Hispánica (1528-1713). Società Ligure di Storia Patria, pp. 191-202.

Glete, J., 2002. War and the state in early modern Europe: Spain, the Dutch Republic, and Sweden as fiscal-military states, 1500-1660, Warfare and history. Routledge, London; New York.

González Presbítero, T., 1829. Colección de cédulas, cartas-patentes, provisiones, reales órdenes y otros documentos concernientes a las provincias vascongadas: copiados de orden de S.M. de los registros, minutas y escrituras existentes en el Real Archivo de Simancas, y en los de las secretarías de Estado y del despacho y otras oficinas de la Corte. Imprenta Real, Madrid.

Grafe, R., 2012. Distant Tyranny: Markets, Power, and Backwardness in Spain, 1650-1800. Princeton University Press, Princeton.

Grafe, R. and Irigoin, A., 2012. A stakeholder empire: the political economy of Spanish imperial rule in America. The Economic History Review, 65 (2), 609651.

Greif, A., 2006. Institutions and the path to the modern economy: lessonsfrom medieval trade, Political economy of institutions and decisions. Cambridge University Press, Cambridge; New York.

Hernández Esteve, E., 2013. Aproximación al estudio del pensamiento contable español: de la Baja Edad Media a la consolidación de la contabilidad como asignatura universitaria. Asociación Española de Contabilidad y Administración de Empresas, Madrid.

Hernández Esteve, E., 2010. La historia de la contabilidad, vía privilegiada de aproximación a la investigación histórica: cuentas de los fondos recibidos por la Factoría General de los reinos de España para financiar la guerra de Felipe II contra el Papa Pablo IV y Enrique II de Francia (1556-1559). Real Academia de Doctores de España, Madrid.

Hernández Esteve, E., 2003. Guerra, gestión experta y contabilidad en la Real Hacienda. Movimientos Internacionales de fondos a través de la Factoría General de los Reinos de España (1556-1557). In: De Computis et Scripturis. Real Academia de Ciencias Económicas y Financieras, Barcelona, pp. 241-306.

Hernández Esteve, E., 1984. Las cuentas de Fernán López del Campo, primer factor general de Felipe II, para los reinos de España (1556-1560). Hacienda Pública Española, 87, 85-105.

Irigoin, A. and Grafe, R., 2013. Bounded Leviathan: Fiscal constraints and financial development in the early modern Hispanic world. In: Questioning Credible Commitment: Perspectives on the Rise of Financial Capitalism. Cambridge University Press, Cambridge, pp. 199-227.

Jago, C., 1981. Habsburg Absolutism and the Cortes of Castile. The American Historical Review, 86, 307-326.

Jeon, B., 2014. Sixteenth Century Spanish Fiscal Mismanagement and Debtor Emperors: An Economic History Review of Spain under Charles V in 1528 and under Philip II in 1575. Carnegie Mellon University, Pittsburgh.

Keefer, P. and Shirley, M. M., 2000. Formal versus informal institutions in economic development. In: Mènard, C. (ed.). Institutions, Contracts and Organizations: Perspectives from New Institutional Economics. Edward Elgar Publishing, pp. 88-107.

Koenigsberger, H. G., 1978. Monarchies and Parliaments in Early Modern Europe Dominium Regale or Dominium Politicum et Regale. Theory and Society. 5 (2), 191-217.

Lapeyre, H., 1981. El comercio exterior de Castilla a través de las aduanas de Felipe II. Universidad de Valladolid, Facultad de Filosofía y Letras, Valladolid.

Lapeyre, H., 1974. Les exportations de laine de Castille sous le règne de Philippe II.: In: Spallanzani, M. (ed.), La lana come materia prima : i fenomeni della sua produzione e circolazione nei secoli 13-17: atti della prima settimana di studio, 18-24 aprile 1969 . Presented at the La lana come materia prima. I fenomeni della sua produzione e circolazione. Secc. XIII-XVII. Prato, 18-24 aprile 1969, L. S. Olschki, Firenze, pp. 221-239.

Lorenzo Sanz, E. (ed.), 1986. Historia de Medina del Campo y su tierra. Ayuntamiento de Medina del Campo, Consejería de Educación y Cultura de la Junta de Castilla y Leon, Valladolid.

Lynch, J., 1992. The Institutional Framework of Colonial Spanish America. Journal of Latin American Studies. 24, 69-81.

Marcos Martín, A., 2006. Deuda pública, fiscalidad y arbitrios en la Corona de Castilla en los siglos xvı y xvı. In: Sanz Ayán, C. and García García, B. J. (eds.). Banca, crédito y capital. La monarquía hispánica y los antiguos Países Bajos (1505-1700). Fundación Carlos Amberes, Madrid.

Maréchaux, B., 2017. Instituciones navales y finanzas internacionales en el Mediterráneo de la época moderna: los asentistas de galeras genoveses al servicio de la monarquía hispánica (1500-1650). Carlos III de Madrid, Madrid. 
Martín, F. R., 1968. Las finanzas españolas durante el reinado de Felipe II (alternancias de participación que se ofrecieron para Francia). Hispania: Revista Española de Historia, 2, 109-174.

Mazín Gómez, Ó., 2012. Architect of the New World. Juan de Solórzano Pereyra and the Status of the Americas. In: Cardim, P. (ed.). Polycentric Monarchies: How Did Early Modern Spain and Portugal Achieve and Maintain a Global Hegemony? Sussex Academic Press, Brighton; Portland, Oregon, pp. 27-42.

Miller, J., 1990. Absolutism in Seventeenth-Century Europe. Macmillan International Higher Education.

North, D. C., 1997. Institutions, transaction costs, and the rise of merchant empires. In: Tracy, J. D. (ed.). The Political Economy of Merchant Empires: State Power and World Trade, 1350-1750. Cambridge University Press, Cambridge, pp. 22-40.

North, D. C., 1990. Institutions, Institutional Change and Economic Performance. Cambridge University Press, Cambridge.

North, D. C. and Weingast, B. R., 1989. Constitutions and Commitment: The Evolution of Institutions Governing Public Choice in Seventeenth-Century England. The Journal of Economic History, 49 (4), 803-832.

Parker, G., 2014. Imprudent king: a new life of Philip II. Yale University Press, New Haven.

Parrott, D., 2012. The business of war: military enterprise and military revolution in early modern Europe. Cambridge University Press, Cambridge.

Perrone, S. T., 2008. Charles V and the Castilian Assembly of the Clergy negotiations for the ecclesiastical subsidy, Studies in the history of Christian traditions. Brill, Leiden.

Phillips, C. R. and Phillips Jr., W. D., 1997. Spain's golden fleece: wool production and the wool trade from the Middle Ages to the nineteenth century. Johns Hopkins University Press, Baltimore.

Rodriguez-Salgado, M. J., 1988. The Changing Face of Empire: Charles V, Philip II and Habsburg Authority, 1551-1559. Cambridge University Press.

Romano, R., 1949. Banchieri genovesi alla corte di Filippo II. Rivista Storica Italiana, 61, 241-247.

Ruiz Martín, F., 1990. Pequeño capitalismo, gran capitalismo: Simón Ruiz y sus negocios en Florencia, Historia del mundo moderno. Crítica, Barcelona.
Sánchez Camacho, A., 2018. State and monasteries: local finances in the state building process, Workshop "Is There Space in Cities for State-Building? Early Modern Processes in an Urban and Global Scope: Agents, Practices, and Discourses", held at the European University Institute. Florence. Comunicación personal.

Sanz Ayán, C., 2015. Un banquero en el Siglo de Oro: Octavio Centurión, el financiero de los Austrias. La Esfera de los Libros, Madrid.

Stasavage, D., 2011. States of credit: size, power, and the development of European polities, Princeton economic history of the Western world. Princeton University Press, Princeton, NJ; Woodstock.

Thompson, I. A. A., 2002. Castile: Absolutism, Constitutionalism, and Liberty. In: Hoffman, P. T. and Norberg, K. (eds.). Fiscal Crises, Liberty, and Representative Government, 1450-1789, The Making of Modern Freedom. Stanford University Press, pp. 181-225.

Tilly, C., 1990. Coercion, capital, and European states, AD 990-1990, Studies in social discontinuity. Blackwell, Cambridge, Mass, USA.

Torres Sánchez, R., 2016. Military Entrepreneurs and the Spanish Contractor State in the Eighteenth Century. Oxford University Press.

Torres Sánchez, R., 2007. War, State and Development: fiscal-military States in the Eighteenth Century. Ediciones Universidad de Navarra. EUNSA, Pamplona.

Tracy, J. D., 2002. Emperor Charles V, impresario of war: campaign strategy, international finance, and domestic politics. Cambridge University Press, Cambridge, U.K.; New York.

Ulloa, M., 1986. La Hacienda Real de Castilla en el reinado de Felipe II, 3rd edition (first published in 1963). ed. Fundación Universitaria Española, Seminario Cisneros, Madrid.

Waters, T. and Waters, D. (eds.), 2015. Weber's rationalism and modern society: new translations on politics, bureaucracy, and social stratification. Palgrave Macmillan.

Wilson, P. H., 2000. Absolutism in Central Europe. Psychology Press.

Yun-Casalilla, B. and O'Brien, P. K. (eds.), 2012. The Rise of Fiscal States: A Global History, 1500-1914, Cambridge Books Online. Cambridge University Press Cambridge. 